\title{
Christie Davies
}

\section{Hašek, ŠvejK ANd The Poles}

\begin{abstract}
The Good Soldier Švejk is often seen as an anti-war book satirising militarism. It is not. It is a consistent piece of fierce and ribald mockery of all those nations and bureaucratic institutions who had stood in the way of Czech nationalism and independence. By chance the Poles happened to be one of these nations. For Hašek and many of his Czech contemporaries the Poles were the very antithesis of the Czechs. During World War I nationally-conscious Czechs hoped that the Orthodox Russians would rescue them from oppression by the Roman Catholic Austrians; the intensely Catholic Poles hoped for exactly the opposite. The Poles revered their aristocrats and their Church whilst the Czechs were egalitarian individualists, a tradition which Masaryk saw as Hussite in its origins. Czech identity was born in those proto-Protestant times and crushed by the Catholic Hapsburgs as part of the Counter-Reformation. This is one reason why there is such savage mockery of individual Poles as soldiers, aristocrats and priests in Hašek's work. The Poles stood for hierarchical forms of social order that Hašek, an anarchic Czech nationalist, detested and which he attacked with an often obscene and scatological humour, particularly the Roman Catholic Church.
\end{abstract}

\section{Key words}

Humour; mockery; pollution; Austro-Hungary; T. G. Masaryk; Catholics; aristocrats; Jaroslav Hašek; Švejk; Poles

It might at first seem strange that a study of Švejk and Hašek should be devoted to a detailed account of their relations with the Poles. Švejk only gets to Poland in the third chapter, From Hatvan to the Galician Frontier, of the third book of Hašek's masterpiece The Good Soldier Švejk and his Fortunes in the World War. Yet today there are statues of Švejk in the Polish towns of Sanok and Przemyśl, two of the towns mentioned in Švejk's adventures. One wonders whether the Polish authorities who put them there had read with sufficient care 
Hašek's relentlessly mocking account of the ludicrous and at times venal Poles encountered by Švejk. We should though also note the earlier appearance of an inane Polish major-general in Budapest who arrives to check the transport arrangements and in particular the latrines, for the conveying of Švejk's regiment across Hungary towards the front (Hašek 1973[1923]: 533-540) and of the incomprehensible Wasserpolak sergeant-major who had had to deal with Švejk and Sapper Vodička in Kiralyhida (Hašek 1973[1923]: 394). However, to study Hašek's Poles really is important, for it reveals or at least reinforces our understanding of the framework within which Hašek's mocking and ridicule is made, a framework which contains distinctive patterns. Hašek's humorous attacks are not random. Fully to understand why Hašek made fun of particular groups, it is necessary to identify the groups he could have ridiculed but either does not even mention or, as in the case of the Ruthenians, treats only with sympathy and never ridicule.The inclusion of the Poles in the list of groups he has ridiculed when other groups encountered by Švejk have not been so treated provides an excellent indication of what Hašek was thinking.

The argument that will be advanced here is that the Poles are the antithesis of Hašek's imagined version of the nationally-conscious Czechs of Bohemia. The Poles were not the enemies and oppressors of the Czechs in the sense that the Austrian, Hungarian and German-Bohemian supporters of the Habsburgs were (Brook-Shepherd 1968: 163, Sked 2001: 226, Steed 1914: 22-24, 77, Taylor 1948: 147, Zeman 1961: 97) but they were not a downtrodden Slav minority either. They were rendered comic because they were the antithesis of Hašek's "ideal" Czechs. When Hašek makes fun of his Czech fellow countrymen, he treats them as particular individuals pursuing their diverse interests and carrying out their tasks and duties in life in a silly or dubious way but he makes fun of the Poles simply as Poles. There are many sympathetically observed Czechs in The Good Soldier Švejk from Lieutenant Lukáš and the well-educated one year volunteer Marek to the humble country people of South Bohemia who help Švejk during his Anabasis but no Poles are to be found in this category. The Poles are all without exception buffoons. The Poles ought to be brothers but they behave like others.

The hypothesis advanced here is that Hašek sees the Poles and the Czechs in terms of a series of dichotomous oppositions, oppositions that inform all his humour but which here can be seen with particular clarity. It will be argued that this pattern has not been arbitrarily constructed by Hašek, who undoubtedly could be arbitrary, anarchic, chaotic, but draws on cultural patterns existing in the minds of other groups of Czechs at the time when he was writing The Good Soldier Švejk in 1921-23 and indeed in some measure during and before World War I. Hašek's Czech/Polish antitheses are summed up in Table 1 below: 


\begin{tabular}{|l|l|}
\hline Czechs & Poles \\
\hline Anti-Habsburg & Loyal to Habsburgs \\
\hline Anti-Catholic & Fiercely Catholic \\
\hline Classless & Aristocratic \\
\hline Sympathetic to Russians and Ruthenians & Hostile to Russians and Ruthenians \\
\hline
\end{tabular}

Table 1. Czech/Polish antitheses in Švejk

This Table should not be taken as an attempt at a balanced and objective twentyfirst century historical analysis. It owes much to Czech national myths and interpretations, particularly those espoused by the President-Liberator Tomáš Garrigue Masaryk, whose validity may be challenged (Gellner 1995). It is rather an attempt to gain a fuller understanding of the mind of Hašek the author of The Good Soldier Švejk and also to provide an interpretative understanding of the culture of those Czechs who shared some of his sentiments, which in turn casts light on the making of his master work.

\section{Hašek's Poles}

The characteristics of Hašek's Poles are well illustrated in his brief description of the Polish member of the mutually unintelligible multi-national set of guards who are taking Švejk back to his unit under escort after his farcical court-martial in Galicia for being a suspected Russian spy.

The Pole in the escort behaved like an aristocrat. He took no notice of anyone and amused himself on his own by blowing his nose on the ground very cleverly using for the purpose the fingers of his right hand. After that he gloomily smeared it with the butt of his rifle and in a well bred manner wiped the sticky butt of the rifle on his trousers, muttering all the time: 'Holy Mother of God'.

Hašek (1973[1923]: 718-719)

The Pole of this little vignette is a loyal Habsburg guarder of a deviant Czech, his oath is distinctively Catholic and he has the air of a proudly aloof member of the Polish noble and gentry class, the szlachta. Yet his behaviour is ludicrously absurd, for he is performing a gratuitously repulsive action with the care and refinement of a civilised aristocrat, one who should not behave in this way at all (Elias 1978). Only Hašek could have invented such an ironic and paradoxical image and he has deliberately pinned it on a Pole. The Pole is conscious of his own sense of high status but not of the disgust of others. Not surprisingly, Švejk caps the incident with a Czech tale of his own linking high and low in an incongruous way, for we have in fact met a ludicrously proud Polish aristocrat before, 
irrelevantly placed in one of Švejk's absurd responses to an army superior who calls him a degenerate:

Humbly report, sir, at the corner of Na Bojisti and Katerinska Street where I live, there was once a degenerate. His father was a Polish count and his mother a midwife. He used to sweep the streets but in the bars he never allowed anyone to call him anything else than "My Lord".

Hašek (1973[1923]: 237)

The Polish aristocrat in reduced circumstances, a standard figure of fun, is at the centre of Švejk's pleasurable excursion to search for his enemy, Lieutenant Dub, who was missing from an urgent conference of the battalion's officers because he was dallying with a Miss Ella in The Combined Halls of Entertainment and Town Café, a brothel in the Polish town of Sanok. Today there is a statue of Švejk sitting on a bench in Sanok but whether this indicates the actual site of the brothel is unclear. Against the wishes of the Polish madam, Švejk rushed into the brothel and headed upstairs to look for the errant Dub. The owner of the brothel "an impoverished Polish nobleman" ran after Švejk and catching him by the tunic shouted in German that the upstairs was "reserved for the officer gentleman" and that the other ranks must confine their sexual cavorting to the ground floor. Švejk explained that for vital military reasons he must urgently find Lieutenant Dub. The proud Polish aristocrat became more and more aggressive and Švejk knocked him down the staircase (Hašek 1973[1923]: 620-621), an incident carefully drawn by Josef Lada, who has dressed the tumbling Pole in an elegant tailcoat. It is a familiar humorous story, the man of aristocratic status but no economic resources or useful skills being forced to take on a sordid occupation, in this case one for which he is curiously fitted by his possession of an urbane bearing and fine manners, which will please and flatter his officer customers and make them feel at ease. As a Polish aristocrat in the Galician crossroads of empire, he will be used to dealing with gentlemen of other nations and having a command of many languages. His position is paradoxical and yet somehow also appropriate. His task is to maintain social distinctions, symbolised by the segregation of officers and men, with the officers' sexual encounters taking place on a higher floor, almost a higher plane, on the first floor, the piano nobile, the noble, the principal floor. When Švejk, the egalitarian Czech hurls him down a floor, it is a metaphor of what has happened in his life, as a now "impoverished nobleman", a member of a characteristically Polish and Galician class, the poor szlachta. Hašek has as usual turned hierarchical order into chaos through an act of Švejk.

Earlier when Švejk had travelled through Bruck an der Leitha on the border between Austria and Hungary, Hašek had already noted and invited laughter at the segregation of army brothels by rank. The Maize Cob which had been visited by the Archduke Stephen during the great manoeuvres at Sopron in 1908 was for officers only, while the ordinary soldiers and one year volunteers had to go to The House of Roses, which could only manage a green light and not a red one. 
At the front itself transportable Imperial and Royal brothels organised by the brigade staff were divided into those for officers, NCOs and men respectively (Hašek 1973[1923]: 351), a tripartite division reflecting the nature of the military hierarchy. It is a characteristic, if at the time irrelevant, observation by Hašek who amuses the reader by pointing to the way in which a very basic natural activity has been slotted into a socially constructed hierarchy. It is not about differences in price or in levels of sophistication but about maintaining divisions in authority created for a military not a sexual reason.

Hašek again confronts the natural, the universal, the spontaneous with the rigidly ordered and hierarchical to produce farce in his account of the inspection in Budapest of the troop trains in which Švejk is travelling by a Polish Major-General, a "gentleman with red and gold stripes on his trousers" (Hašek 1973[1923]: 533), who speaks bad Czech. The obsessional Polish general is one of the great imbeciles on high of The Good Soldier Švejk. He is the Polish answer to the Austrian aristocrat Colonel Friedrich Kraus von Zillergut who can only speak in platitudes (Hašek 1973[1923]: 201-203] and is living proof that a Pole, if stupid enough, could aspire to the highest office under the Habsburgs.

The Polish Major-General's obsessions are with shitting and sleeping. This is fair enough given that fitting these activities in an orderly way into the rigidly organised twenty-four hour timetable of a total institution (Goffman 1961) such as an army, monastery, convent or boarding school creates problems, which if unresolved would lead to a loss of hygiene or to cumulative exhaustion. However, the Major-General does not even understand the direction in which time flows and confuses past and future. He gives an order to Captain Ságner:

"Issue supper at six o'clock", he continued, looking at his watch which showed ten minutes past eleven at night. "At half past eight alarm, latrine shitting, then bed"... In the face of such an army the enemy flees in panic.

Hašek (1973[1923]: 534-535, 538)

The next morning the men went by sections to the latrines to be inspected in action by the general. Hašek describes the event at great length and in some detail culminating in the point where Švejk too stands up in the middle of shitting to salute the Polish major-general.

"Haf you viped your arsch?" the major-general asked Švejk.

"Humbly report, sir, everything is in order".

"Von't you sheet no more?"

"Humbly report, sir, I've finished".

"Vell now pull your hose up and shtand at attention again".

Hašek (1973[1923]: 540)

Hašek often used shitting in this way to represent disorder in the face of military orderliness, making the latter seem absurd. It had happened before when 
a Colonel Schröder, holding a military conference, made use of a map of a battlefield in which the position of the contending armies was indicated by neat rows of coloured flags on pins. During the night the company tom-cat relieved itself on the map and in covering up its mess moved and dislodged the flags and shifted the position of the front-line. It had "stained the front and the bridgeheads and defiled all the army corps" (Hašek 1973[1923]: 436). The short-sighted Colonel Schröder managed "to plunge his finger into one of the little mounds with which the tom-cat had tried to make the map of the battlefield a relief one". The ordered neatness of a military plan had been not only defiled but reduced to disordered chaos, perhaps a foretaste of what was going to happen when it was tested in battle.

The human body with its clean and clear boundaries and purposeful design and structure is the very image and metaphor of social order (Douglas 1966) including military order - 'a fine body of men', 'the body politic' - and it is nurtured by food shaped by the cook. Order begets order. An army marches on its stomach. The antithesis of this are the disordered shapeless, unclean, clinging colloids that the body emits, its shit, vomit and spittle and of course the snot which the Polish soldier guarding Švejk smeared on his neatly tailored Habsburg uniform trousers using the butt of his officially issued rifle. These products of the orifice disturb and disrupt the ordered boundary of the body and correspond to the collapse of a bounded, ordered social hierarchy. They also are the means by which Hašek systematically ridicules and debases the social order. Shit had been extensively used for the same purpose by Rabelais (1953[1532]) and vomit was to be used by the Australian Dada humorist Barry Humphries (Davies 1997, 2002) but the antics of Hašek's Pole provide one of the few uses of snot for his purpose. Another sign of Hašek's originality.

Much fun is also had with the Polish Major-General's attempt to speak Czech which "he pronounced ... as though it were Polish and used Polish expressions":

"You roars like a cow does for his hay. Shot your mog! Dawn't Moo. Hašek (1973[1923]: 535-536)

It is not the only time when a Pole muddles up two languages. A Pole from Kolonyje on sentry duty who is confused over a military password tries to tell an approaching Lieutenant Dub 'I'm going to shoot' but instead in a strange mixture of Polish and German shouts: "I'm going to shit. I'm going to shit" (Hašek 1973[1923]: 572). And of course, there is the Wasserpolak ('water Pole') Sergeant-Major from Silesia who thoroughly mixes up his languages to comic effect (Hašek 1973[1923]: 394).

Hašek often mocks the badly spoken Czech used by Bohemia's Germans since the two peoples have regularly to interact but the Poles are arbitrarily singled out for laughter, probably because they speak a related language that sounds like Czech gone wrong. The Hungarians are foreigners who historically have often been the enemies of the Czechs but cannot easily be imitated because their lan- 
guage is utterly incomprehensible to all their neighbours. When Hašek's Magyars curse and swear vividly, obscenely and blasphemously in Hungarian, a translation has to be provided in a footnote for the Czech reader (Hašek 1973[1923]: 367) and indeed for the readers of Hašek's works translated from Czech into other languages. The Poles, by contrast, are fellow Slavs who, from Hašek's point of view, ought to be on the side of the Czechs but they have perversely chosen to back the 'most Catholic' Habsburg dynasty, the dynasty oppressing the Czechs. When Švejk is arrested because he is thought to be a Czech spying for the Russians and is going to be executed, the 'Czech' informer inserted in his cell to wheedle incriminating information from him, "speaks Czech with a Polish accent" (Hašek 1973[1923]: 685).

\section{Enter the Ruthenians}

In Galicia there were in addition to the dominant Poles two important ethnic minorities, minorities often excluded, disliked and discriminated against by both Poles and Austrians, namely the Ruthenians and the Jews (Zamoyski 1987: 344-345). Both were set apart from the Roman Catholic Poles by religion and language. The Ruthenians were regarded with suspicion by the imperial authorities lest they have Russian sympathies (Steed 1914: 128, Zeman 1961: 3-12, 52). Hašek does not ridicule the Ruthenians as he does all the other groups in the book but treats them with compassion. As the narrator of The Good Soldier Švejk he is clearly shocked by the spectacle of Hungarian gendarmes in Slovakia tormenting and beating up Ruthenian peasants, teachers and priests at the railway station in Humenné (Hašek 1973[1923]: 573). That groveller to Habsburg authority the oak-headed Lieutenant Dub predictably approved of the Hungarians' brutality and claimed that the Hungarians were avenging the assassination of the Archduke Franz Ferdinand and his wife by the Serbs the previous year (Hašek 1973[1923]: 574), being still driven by enraged indignation. In his description of the incident Hašek ceases to use the rollicking language of farce associated with Švejk and does not even use the grimly mordant but fanciful style with which he, as narrator, talks about the battlefields but is bluntly realistic (see also Hašek, 597, 724-725). The gendarmes are simply brutes, not comic or exaggerated brutes but brutes full stop; real-life brutes. Hašek's language here is quite different from the comic way in which he usually narrates tales of brawls and beatings, such as the attack on the Hungarian iron-monger Gyula Kákonyi by Sapper Vodička in Királyhida, which led to a fight in the street between passing Honvéds who came to their countryman's support and Czech soldiers who just happened to be passing by. With a characteristically fine touch Hašek writes of Mr. Kákonyi who has been hurled out of his own house:

Only afterwards by the gate in the carriage entrance Švejk found a tornoff collar. Evidently the last act of this tragedy was performed here when 
Mr. Kákonyi desperately held on to the house gate so as not to be dragged out into the street.

Hašek (1973[1923]: 370)

In this way the entire, otherwise downright nasty, incident is turned into an imagined farce, played out on a stage. The beatings given to the Ruthenians, or to the Galician Jews (Hašek 1973[1923]: 724-725] by contrast are reported with directness as real. Possibly they represent actual incidents witnessed by Hašek when he himself was a soldier travelling to the front. We are not expected to laugh. No-one laughs except, it is recorded, the Hungarian gendarmes who having trussed up a Ruthenian Uniate or Orthodox priest merrily force him to dance a czardas so that he falls over and is injured, probably breaking his nose. Lieutenant Lukáš, a decent Czech officer, was sickened by the incident and Dub's reaction to it to the point of "Weltschmerz" (Hašek 1973[1923]: 574) and readers are clearly expected to share his feelings. Later a Ruthenian Orthodox priest and a rabbi are hanged by the Austrian army (Hašek 1973[1923]: 699]. They are not part of a fight which could have been rendered funny but are simply, victims. It is important to note which groups are not the subject of Hašek's mocking humour in order to understand why other groups are. Hašek did not choose his ethnic, political and religious targets at random.

The last appearance of the Poles in The Good Soldier Švejk is when a Polish headmaster mendaciously denounces the local Greek Catholic vicar to the Habsburg military authorities as having celebrated a mass for the Russian Orthodox Tsar and has him hanged (Hašek 1973[1923]: 727). His huge school had been built by the Polish authorities in a purely Ukrainian area to Polonise the local people (Hašek 1973[1923]: 727, Okey 2001: 288) but there is a more material side to the denunciation for the hanging involved "nationalism, religious strife and a hen". After his death the vicarage was looted with "one Polish peasant stealing his piano so as to construct a pigsty from it" (Hašek 1973[1923]: 727-728). What would Paderewski, patriot and pianist, have thought about this or indeed the ghost of Szopen whose own piano had been destroyed by the Russians in 1863, fourteen years after his death? The Russian soldiers first shat in the piano and then hurled it out of a fourth floor window, an anecdote later used to telling effect by Milan Kundera as a metaphor. But the conflict between the Poles and the Slavs to their East - Ruthenians, Ukrainians, Byelorussians, Russians - was of long standing, particularly in Eastern Galicia and was to continue long after World War I. There is even a British humorous anecdote about it:

After World War I the Poles wanted their new frontier with Russia to be far further east than the one proposed on the basis of population by George Nathaniel Curzon the British foreign secretary, known as the Curzon Line. Paderewski, the concert pianist who had become a leading Polish politician, confronted the British Prime Minister David Lloyd George who was 
reluctant to agree to large Ruthenian, Ukrainian and Byelorussian minorities being incorporated into Poland.

Paderewski declared: "If you do not agree to my demands, the Polish people will be so angry that they will go out into the streets and beat up the Jews". Lloyd George: "And what if I do agree to what you want?"

Paderewski: "The Polish people will be so overjoyed that they will rush out enthusiastically into the streets and beat up the Jews."

It is fairly clear whose side Hašek was on in these conflicts. It was not that of the Roman Catholic Poles.

\section{The Catholic Enemy}

Hašek was as angry at and contemptuous of the Catholic Church as he was of the Habsburg monarchy (Parrott 1978: 35). He saw both of them as powerful autocratic hierarchies that each in its own way boxed in and restricted the freedom of ordinary people. For him they were also closely allied - the throne-gun-altar complex. There is a curious affinity with Masaryk's view that political absolutism derived from Church absolutism and that the Habsburgs represented theocratic absolutism (Gellner 1995: 46). Priests, soldiers, bureaucrats seemed to be the castes who ran everything in a co-ordinated way (Steed 1914: xxv-xxxi) and this is how they are depicted in The Good Soldier Švejk (Hašek 1973[1923]: 594). They are the alien external controllers whom Švejk has to outwit using ludicrous tactics to outmanoeuvre ludicrous authority. Hašek writes in passing of the gunthrone-altar alliance:

His Eminence, the Archbishop of Budapest (Gerzas of Szatmar-Budafal) used in his prayers such beautiful sentences as for instance "God bless your bayonets that they may pierce deep into your enemies' bellies. May the most just Lord direct the artillery fire on to the heads of the enemy staffs. May merciful God grant that all your enemies choke in their own blood from the wounds which you will deal them ... the only thing missing in these little prayers was Baszom a Kristus Máriát! [Fuck Christ and the Virgin Mary]

Hašek (1973[1923]: 523)

How much history Hašek knew is uncertain but he may well have been aware that the armies taking part in the Papal crusade of 1420 against the Bohemian Hussites, the morning star of Protestantism, were provided by the Hungarians and the German princes. The Czech nation was born in this proto-Protestant rebellion (Martin 1978: 103). The Habsburgs who decided to extirpate Protestantism and extinguish Czech independence after the Battle of the White Mountain (Hermann 1975: 56) in 1620 were part of a fiercely bigoted Jesuit led Counter-Reformation 
and the battles in Bohemia set off the Thirty Years War. The Habsburg Emperor Ferdinand II said "Better a desert than a land of heretics" (Steed 1914: 5) and that is what Bohemia became. Ferdinand made a desert and called it peace. Those Czech Protestants who could emigrated and the Czech peasants were forcibly converted to Catholicism. They conformed outwardly but were inwardly alienated and many quit the Catholic Church altogether when the Habsburg dynasty fell (Martin 1978: 233). For the fanatical Ferdinand II his devotion to the Church was more important even than his royal office but by Hašek's time the church was more a branch of the Habsburg state than the state was an arm of the church. But the fusion of interests remained (Steed 1914: 107, 115-117). The anti-Habsburg Hašek's obsession with the Catholic Church was not as irrational as it might seem. There was Methodism in his madness.

Perhaps the best remembered Catholic incidents in The Good Soldier Švejk involve the drunken and dissolute military chaplain Otto Katz when Švejk was his batman. But it goes far beyond mere anti-clericalism. In his description of the farcical drumhead mass arranged and presided over by Katz, Hašek does not merely express anti-clericalism but mocks and undermines the central beliefs, mysteries and sacred rituals of the Catholic faith (Parrott 1982: 52) to the point where even his English translator Sir Cecil Parrott (1973: xvii) felt obliged to protest. Hašek spends an entire nine pages describing and discussing just this one sacred ceremony; he is at the height of his descriptive powers and wildly inventive and imaginative in his use of imagery.

The altar made for the mass had been made by the Viennese Jewish firm Moritz Mahler. Painted in screaming colours it appeared from a distance like a coloured chart intended for testing colour-blind railway workers. One figure stood out prominently - a naked man with a halo and a body which was turning green, like the parson's nose of a goose which has begun to rot and is already stinking. No one was doing anything to this saint. On the contrary, he had on both sides of him two winged creatures which were supposed to represent angels. But anyone looking at them had the impression that this holy naked man was shrieking with horror at the company around him, for the angels looked like fairy tale monsters and were a cross between a wild cat and the beast of the apocalypse.

Hašek (1973[1923]: 130-131)

Švejk was the server and wheeled around the priestly Katz "like a Red Indian dance around a sacrificial stone" (Hašek 1973[1923]: 133), while the men and the officers smoked throughout. Rarely has a sacred ceremony been so thoroughly profaned. And it all ends badly:

Švejk said to the chaplain: Humbly report, sir, must a server be of the same confession as the man he's assisting?"

"Of course", answered the chaplain, otherwise the mass wouldn't be valid". 
"Then, sir, a great mistake has been made", said Švejk.

"I'm a man without confession. It's always me that has the bad luck."

Hašek (1973[1923]: 133)

It was not the only drumhead mass to be mocked in The Good Soldier Švejk, for Senior Chaplain Ibl held another in Bruck an der Leitha when Švejk's unit was travelling to the front. This time Hašek uses not farce but parody and Švejk sums up the entire false splendour of a sacred occasion glorifying slaughter as "utter bunkum" (Hašek 1973[1923]: 448). As if this were not enough, the last rites, extreme unction, are ridiculed on two separate occasions (Hašek 1973[1923]: 130, 139-155] as it already had been in Hašek's pre-war short story, An Idyll from the Almshouse in Zizkov (Hašek 1983: 60-64). In a further short story, The Battle for Souls, Hašek (1991[1913]: 121-130) ridiculed the moral basis of the Catholic confessional and he did so again in The Good Soldier Švejk (Hašek 1973[1923]: 594-595). Hašek had a long and prolific history of writing anti-Catholic stories, squibs and feuilletons (Parrott 1982: 79). The priests, catechists and pious Catholic believers whom Švejk encounters are all either utterly venal or else complete simpletons (Hašek 1973[1923]: 428, 442, 593-594, 647, 648, 694-707). Hašek either places one of these despised Catholics in a tale told by Švejk or else directly in the narrative, so that the Catholic Church becomes the institution next most frequently ridiculed after the army. As he had done with the army, Hašek routinely uses shit in his mocking of the church as when he tells the reader at length how copies of The Song of Lourdes in many languages that were distributed by the Polish vicar of Tyrawa Wołowska all end up in the latrines. Yet the oddest case is when Švejk reminisces about the time when he was apprenticed to a highly religious apothecary. His boss, Mr. Kokoška, had read that evocations of St. Pelegrinus helped when cattle got flatulent, so he had had images of St. Pelegrinus printed and consecrated at the Emmaus for two hundred guilders. He decided that, when the herbs from his shop were given to the cows to stop them farting, a prayer to St. Pelegrinus should be recited to the cow and he told his assistant Mr. Tauchen to compose one to be printed on the reverse of the image of the saint. Mr. Tauchen delegated the job of composing an evocation of St. Pelegrinus in verse to Ferdinand the porter but then failed to pay him. Ferdinand sought revenge on Mr. Tauchen through the defiling of the sanctified cow-herbs.

Švejk: "Whenever Ferdinand was able to sweep up mouse droppings he brought them up there and mixed them into the herbs. And then he collected horse manure in the streets, dried it at home, pestled it in a mortar and threw all that too into our cow-herbs with the picture of St. Pelegrinus. But, that was not the end of it. He pissed into those boxes, shitted into them and stirred it up all together so that it was like a bran mash." 
We shall never know what effect Ferdinand's noisome slurry had on the farting cows since the phone rang and Švejk's listener Quartermaster Sergeant-Major Vaněk, himself an apothecary in civilian life, was called away. Did the cows now release ever more methane and contribute to global warming? What we do see is Hašek once more reducing the sacramental to the excremental. Pelegrinus' holy image has been pounded into and compounded with the lower body products of in turn mice, horses and of Ferdinand himself. Oh vile!

The Church and the military are both sacred hierarchies dealing with life and death and high ideals that contrast with the mundane world. They are both, and this is true of the aristocracy as well, staffed by men obsessed with tiny differences in rank and status and with wearing the correct forms of dress and decoration and spotless and colourful robes and uniforms. Shit is the antithesis of this - dirty, formless, shapeless, disordered, defiling, dangerous, a material product of the lower body that is the opposite of the refined mind and pure soul. That is why Hašek consistently linked these opposed worlds. He believed that shit like entropy will always prevail thanks to the second law of thermodynamics, a law that would have been dear to the heart of the anarchic Hašek, had he known about it.

It is important to note that Hašek's laughter at the expense of the Russian Orthodox church in The Bugulma Stories (Hašek 1983: 2-51) is much gentler and more sympathetic than in his savage mockery of the Catholics (Parrott 1973: xvii, 1983: xiii). His Bugulma story The Procession of the Cross ends:

The same evening a young and pretty nun brought me a small icon and a letter from the aged igumen containing the simple sentence "I am praying for you". Since that day, I sleep in peace because I know that up to the very day in the old oak forests of Bugulma there is the Convent of the Most Holy Virgin, where an aged igumen lives and prays for me, wretched good-for-nothing that I am.

Hašek (1983: 18)

Ironic this may be, but there is a dreaming sentimental undertow that is utterly lacking in Hašek's satires on and parodies of Catholic practice. The Orthodox icon given to Hašek by the pretty nun is never going to be savagely ridiculed like the paintings on Otto Katz field altar nor is it ever going to suffer the indignities suffered by the image of St. Pelegrinus at the hands of Ferdinand.

To the Polish mind Hašek's gentleness to the Orthodox Church and spleen against the Catholics must seem perverse, abhorrent, almost incomprehensible. Surely, the Poles will think, it should be the other way round? Once again the Poles and Czechs are each the antithesis of the other. For Czechs like Hašek, the Catholic Habsburgs were the oppressors, and the deniers of Czech freedom, whereas the Orthodox Russians were viewed with Slavophile sympathy, indeed seen as possible future friends and liberators. In World War I many Czechs joined the Czech Legion and fought on the Russian side and some of the Czech settlers 
in Russia converted to the Orthodox Church as well as taking Russian nationality so that they could fight for the Tsar (Zeman 1961: 93).

For the Poles of Galicia it was the Orthodox Russians who were the oppressors, for it was they who had seized the greater part of historic Poland during the partitions and again after Napoleon (Davies, N. 1986: 163). Successive nineteenth-century Polish uprisings against the Russian occupier were crushed with great violence and marked reprisals. The Orthodox Russians regarded their Polish Catholic underlings with disdain. Fyodor Dostoyevsky in his novel about the Russian Orthodox Church, The Brothers Karamazov (1880), refers slightingly and gratuitously to "craven little Poles" scuttling away from their Russian superiors. Dostoyevsky's Poles were at best obsequious card-sharpers and one of the villains in his novel The Idiot (1955[1868-9]: 659-660] is a fake Polish count, a real and Catholic Pole with an invented title and entirely imaginary riches seeking a Russian wife. Dostoyevsky's Grand Inquisitor who denies Christ is of course a Roman Catholic; for the committed to Orthodoxy Dostoyevsky Catholicism was worse even than atheism.

It was a true clash of religious civilizations, a clash that can be seen elsewhere in our own time when Yugoslavia broke up violently in 1990-92 into its angry constituent parts, Orthodox Serbia and Catholic Croatia. During World War II Croatian Franciscans on horseback, allied with the Ustaše, had hunted down fleeing Serbs at a time when Catholic Croatia like Slovakia had a Catholic clergyman as leader. Well over 300,000 Serbs were murdered in Croatia and Bosnia, as were very many Jews. The old religious fault lines of Europe have shown a stubborn persistence.

In the light of all this the Poles of Galicia very sensibly supported the Catholic Habsburgs (Taylor 1948: 150), who had also granted them much autonomy and upheld the authority of Polish aristocrats over Ruthenian peasants (Zeman 1961: 2, 47-48, Zamoyski 1987: 305). Where some Czechs at least sought independence through fighting alongside the Russians, many Poles sought Polish independence by serving in 1914-16 in the Polish Legions, a unit that fought for the Habsburgs wearing its own Polish uniforms and was commanded by Józef Piłsudski (Zeman 1961: 48, Zamoyski 1987: 333), later head of an independent Polish state. There is an irony in the placing of a statue of the Russian-sympathising Švejk in Przemyśl, the city where the Polish Legions were founded, the Legions who were to fight so hard to stem the Russian advances into the Austro-Hungarian Empire.

Thus behind the cultural dichotomy of Poles and Czechs that was part of Hašek's consciousness there was a historic dichotomy based on the utterly opposed experiences of the two peoples in regard to foreign occupation and dominance, experiences with a very strong religious dimension.

\section{Hašek and the Hussites}

The pious, self-disciplined hard-working Hussites (Zeman 1946: 21) would not have approved of the disordered and dissolute Jaroslav Hašek and he would have 
found it difficult to adapt to their ways. Yet it is not as simple as that. After Hašek had voluntarily become a Russian prisoner of war, he went on to become in 1916 a secretary to and writer for the newly organised Jan Hus regiment of the Czech Rifle Brigade, made up of Czechs who now wanted to fight against the AustroHungarian empire. The other regiments were also named after Hussite generals Jiří z Poděbrad, Jan Žižka z Trocnova a Kalicha and Prokop Veliký. The regiments were set to reverse history, to restore the pristine Czechness that had preceded the long imposition of Habsburg-Austrian-Catholicism. Later Hašek was to join the Bolsheviks, whose single-minded puritanical determination in pursuit of equality had the style of the revolutionary wing of the Hussites. For a time Hašek became, or more likely was coerced to become, a teetotaller and led an organised and disciplined existence, like his distant and radical ancestors in south Bohemia, the Taborites. It was at the time of his earlier brief service with the Czech Legion that Hašek wrote The Good Solder Švejk in Captivity as Czech propaganda (Parrott 1978: 166, Parrott 1982: 66). It was a sequel to the irreverent, though fairly mild, Švejk stories he had published before World War I (Hašek 1983: 192-219) and the precursor of his unflinchingly anti-Habsburg, anti-military and anti-Catholic account of Švejk 's wartime adventures in 1914-15, his final masterpiece.

Hašek and the Hussites had the same enemies, the Catholics, the Germans, the Hungarians, the aristocracy and their armies. The Hussites were the radical common people fighting with pike and flail and moving fortresses of linked farm wagons and became part (Zeman 1976: 32) of the anti-aristocratic myth of Czech history used to justify the later ethos of a distinctively Czech moralized egalitarian individualism, the secular creed of Masaryk invoking the spirit of Tabor (Hermann 1975: 167-168). When Vodička fought the Magyars in the streets of Kiralyhida he defended himself with "his bayonet hanging on his belt like a flail" (Hašek 1973[1923]: 370); the flail was the weapon used by the Hussites against the Hungarian armies of King Sigismund, many of them feudal aristocrats on horseback in heavy armour.

The Good Soldier Švejk effectively begins (Hašek 1973[1923]: 6] in the U Kalicha (At the Chalice), a pub named after the symbol of the Hussites, the chalice, and it was planned that it would end there with the reunion of Švejk and Vodička at six o'clock in the evening after the war was over (Hašek 1973[1923]: 395). In a traditional Catholic mass only one part of the sacred bread and wine is given to the lay communicants, the host, the bread or wafer. The consecrated wine in the chalice is drunk only by the priest and he must drink the lot, lest it fall into unpriestly hands. Otto Katz was punctilious about this on the occasion of Švejk's drumhead mass.

There was a whirl of dust and a grey rectangle of uniforms bowed their knees before Lieutenant Wittinger's sport's cup which he won for 'SportFavorit' in the Vienna-Modling race.

The cup was filled full and the general opinion in the ranks of the chaplain's manipulations was: "He swilled it all right!" 
However, in Hussite times, the Ultraquists demanded that the chalice should also be given to the laity so that they could take communion in both kinds, as had been the practice in the early church (Kaminsky 1967: 98, 121, 125). It was the first of the Hussites' Four Articles of Prague (Kaminsky 1967: 369) demanding church reform. With the development of a modern Czech nationalism in the nineteenth century, the Hussites re-entered the consciousness of the Czech people and the chalice became the symbol of Czech radicalism. In the latter part of the nineteenth century demonstrations for Czech rights and for universal suffrage coincided with commemoration ceremonies for Hus "and the black Hussite flag with the white chalice in the centre was much in evidence" (Parrott 1982: 34).

Hašek chose to locate Švejk in a pub called 'At the Chalice' because its name recalls this symbol of Czech national, political and religious defiance. It is difficult to see otherwise why he would have chosen this particular pub, which he himself had rarely visited, rather than one of those more familiar beer halls and hostelries where he had spent so many merry and rumbustious evenings with his bohemian Bohemian friends (Pytlík 1999: 24).

Decades later the Hussites did recognize their link with Hašek. In 2003 eighty years after Hašek's death his grandson organised a commemoration of him in Lipnice nad Sázavou in South East Bohemia, where Hašek spent his last years and wrote much of his great book. Among those who came to the newly rebuilt pub where he used to write and who drank a toast to Hašek were "representatives of the Hussite church" (Velinger 2003).

I rest my case.

\section{A Polish Sequel}

After 1919 both at the time when Hašek was writing and after his death the contrast between Poles and Czechs that I have outlined remained strong. Indeed there were political and military conflicts between the two countries, notably over Těšín, a valuable coal-mining area with a mixed population of Czechs and Poles. During their war with the Russians in 1919-20 over the disputed Eastern frontier (Davies, N. 1986: 116) the Poles appealed for Czech help but Czechoslovakia decided to remain neutral. In particular the Czechoslovakian government refused to allow the Hungarian army to go across Slovakia, following close to the route taken by Švejk, in order to assist the Poles (Hermann 1975: 158). Having got back into Slovakia, the Hungarians might well have decided to stay. Hašek presumably knew something of what was happening in the outside world while he was writing The Good Soldier Švejk and was influenced by it.

Poland was to remain fiercely Catholic in its days of independence before 1939 and aristocratic in tone. The nobles ceased to be a legal estate in 1921 but the magnates retained their social status. In 1919 Count Potocki said in Paris to Sir Harold Nicholson about Paderewski, "a remarkable man, born in one of my own villages and yet when I speak to him I have the impression of speaking to an 
equal" (Davies, N. 1981: 183). It is a very un-Czech comment (Hermann 1975: 82). The Czech magnates had long since faded from Czech political leadership and the Czechs saw themselves as classless. No Czech would ever have spoken like that about Masaryk. The Polish aristocrat was a figure of fun in the jokes and literature of other countries (Lewis 1953[1922]) and in present-day Poland hrabia jokes about dim counts are popular and resemble Austrian jokes about Graf Bobby and their Hungarian equivalents (Davies 2011: 32-35). There are no jokes about specifically Czech counts.

After 1945 when the Jews had been murdered by the Nazis, the Eastern territories annexed by the Soviets and the Ruthenians deported from Polish Galicia in an act of socialist ethnic cleansing called Operation Vistula, Poland became an utterly homogeneous, fervently Catholic country. To be Polish was to be Catholic (Bilska-Wodecka 2005). It was this identity that was the basis of their resistance to the Soviets, heirs of their nineteenth century Russian oppressor. The Habsburgs were not forgotten. In 2004 Charles I of Austria, Emperor 1916-18, the last of that most Catholic dynasty (Brook-Shepherd 1968), the successor of old Procházka, was beatified by the Polish Pope, Jan Pavel II, following the miraculous healing of a Brazilian nun. What would Hašek have had to say about it? Probably nothing, for by then the political tensions and differences between Poles and Czechs had become unimportant, due to both nations being savagely suppressed by the Nazis and then the Soviets, by the Germans and by the Russians, whose tyrannies were far worse than anything the Emperor Franz-Josef, his government, army, prelates and bureaucracy could ever have imagined, let alone desired. The Habsburgs, including the army, had by the late nineteenth century become milder, more humane, more constrained by law, more plural in their outlook (Gellner 1995: 51, Street 1914: 70); indeed one can infer this from many episodes in The Good Soldier Švejk (e.g. Hašek 1973[1923]: 24-26, 30, 256). Visitors from Britain such as Masaryk's friend and sponsor Henry Wickham Steed (1914: xxv, 61, 70-83) describe the Habsburg bureaucracy as petty, fatuous and legalistic with minor secretarial tasks being undertaken by jurists with doctorates in law but deny that it was brutal. The wilder and more vivid tales of Habsburg oppression related by Švejk or recounted by Hašek are merely fanciful. By contrast such behaviour would become a horribly real part of everyday life for the Czechs in the time of the Soviets, when ruled by Czechs more devoted to Stalin than Lieutenant Dub had been to the Habsburgs and even more willing to abase themselves and inform on others (Kovály 1997[1986]). It would be unfair to expect Gashek the Commandant of the Town of Bugulma to have fully foreseen that this would happen. Where the Poles became ever more Catholic the Czechs became much less so after World War I. Many Bohemian Catholics, the descendants of forced converts or who attended because it was socially useful in Habsburg times left their church (Martin 1978: 233) though the Catholics remained easily the largest confession. The Protestants briefly gained members but in the long run the Czechs became unbelievers (Havlíček 2005), as Hašek and Švejk had been, so that today the Czech Republic is the least religious country 
in Europe (Havlíček 2005: 189-190). Masaryk, brought up a Catholic, became a Protestant (Zeman 1976: 553) and was married to an American Unitarian, the most radically sceptical of the American denominations, as an American joke indicates:

When do you hear the word Jesus in a Unitarian church?

When the Polish janitor stubs his toe.

Masaryk, the author of a book on Hus, admired the American separation of church and state and the free competition of its denominations (Zeman 1975:33). He saw the Hussites and the later Moravian brethren as an ethical inspiration for the Czechs with their emphasis on justice, equality, tolerance, love of humanity and spiritual mission (Hermann 1975: 167), all values that have secular equivalents. He said in 1918 to great public acclaim that Tabor the centre of the radical Hussites was the symbol of the continuity of Czech history and provided a mission and programme for the new Czechoslovak republic (Okey 2001: 301-302). This was an interpretation of Czech history and identity that alienated the Czech Catholics who felt that their own important contribution was being dismissed (Gellner 1995: 49, Hermann 1975: 171).

It is important to stress these radical cultural shifts in Bohemia in the years when Hašek was writing his masterpiece because it indicates that he was less of an eccentric loner utterly out of touch with the new Czech establishment than has been suggested (Parrott 1973: xiv-xv, Parrott 1982: 170). The marked shift to a more secular, democratic and socially equal society that followed the fall of the Habsburgs has an affinity with Hašek's admittedly untidy and inconsistent view of the world. When taken together with the Czechoslovakian government's distancing of itself from the Polish republic it enables us to say with certainty that Hašek and the Poles were poles apart.

\section{How should we now view The Good Soldier Švejk?}

In the light of the analysis above, it is fair to say that The Good Soldier Švejk is not an anti-war novel, nor an anti-militarist novel. Nor is it a humane novel, one in a broad sense calling for the amelioration of the human condition, like the works of Charles Dickens also so rich in humour. We can work out what Hašek is against but not what he stands for. Rather it is a novel expressing an ambiguous and ambivalent humour about national, political and religious conflicts. In these conflicts Hašek takes sides. Hašek mocks everyone as he always had done but mocks those defined as being in some sense on the other side far more than those on his own side, the nationally conscious and committed Czechs. When disaster hits one of the others, as when the Deutschmeister corporal bawling out a military song loses his balance, falls out of his fast-moving train and is spiked on a points-lever and killed, a tragic incident may be played for laughs. Serves him 
right (Hašek 1973[1923]: 484-485). Sapper Vodička's xenophobic antagonisms are extreme and Švejk can see this, yet he remains a valued friend in whose presence the book would have ended if it had been completed. Sympathy is restricted to those on the right side of the conflict, Hašek's side. Humane? No, though there are humane incidents, as when Švejk buys a wounded Hungarian soldier a beer.

It is not an anti-war novel, though it might have become one. Švejk only gets to the front right at the end and most of his adventures occur in Prague or in transit. Hašek has a few comments on war's awfulness but many of them cannot be taken seriously. To quote the even fewer serious and reflective ones and ignore the general tone of the work in order to make it out to be an anti-war book is dishonest. The Good Soldier Švejk has little in common with the tragic and poignant anti-war books published in the 1920s in France, Germany and Britain. Tragic and poignant it ain't. The other books were written by men who had been sincere patriots for the cause of their nation and its army but had been horrified by the human suffering this led to and which they had experienced at first hand.

The First World War was a disaster for all the European countries involved but it had one beneficial side effect. It led to freedom and self-determination for the Czechs and this influenced Hašek more than the broader picture of utter destruction. Hašek, a man who eagerly signed up for the Czech legion and later the Red army can hardly be said to have been against war in general, for no one today takes seriously the British propaganda slogan that World War I was a 'war to end war', a war to establish peace and democracy. It was not, nor did it have that effect. Quite the opposite.

The Good Soldier Švejk certainly is a satire on the military but much of it applies to the irrationality of bureaucracies in general and to other sacred hierarchies, notably the Catholic Church. Many readers are unwilling and unable to see this, for it would destroy their picture of The Good Soldier Švejk as a quintessentially anti-militarist novel. Yet a study of the Poles in Hašek's work shows that my proposition is true.

None of what I have said detracts from the greatness of Hašek's achievement. $\mathrm{He}$ is the greatest and most successful writer of nasty humour that the world has ever known (Davies 2000a, 2000b), beating even Cervantes, Nathanael West, Kingsley Amis and Evelyn Waugh. Let us celebrate that.

\section{References}

Bilska-Wodecka, Elżbieta (2005) "Post communist Religious Revival”. In: Knippenberg, Hans (ed.) The Changing Religious Landscape of Europe, Amsterdam: het Spinhuis, 120-144.

Brook-Shepherd, Gordon (1968) The Last Habsburg. London: Weidenfeld and Nicolson.

Davies, Christie (1999) "The Progress of Australian Humour in Britain". Australian Journal of Comedy 1, 15-32.

Davies, Christie (2000a) "Mr. Polly and the Good Soldier Švejk: A Contrast in Style and Social Context". In: Gajda, Stanisław and Dorota Brzozowska (eds.) Swiat Humoru. Opole: Uniwersytet Opolski, 447-459. 
Davies, Christie (2000b) "The Savage Style of Jaroslav Hašek: The Good Soldier Švejk as a Politically Incorrect Comic Masterpiece”. Stylistyka IX [Stylistyka Czeska], 301-315.

Davies, Christie (2002) The Mirth of Nations. New Brunswick: N.J. Transaction.

Davies, Christie (2011) Jokes and Targets. Bloomington, IN: Indiana University Press.

Davies, Norman (1981) God's Playground. A History of Poland, Vol. 2, 1795 to the Present. Oxford: Clarendon.

Davies, Norman (1984) Heart of Europe. A Short History of Poland. Oxford: Oxford University Press.

Dostoyevsky, Fyodor (1955[1868-9]) The Idiot. Harmondsworth: Penguin.

Dostoyevsky, Fyodor (1958[1880]) The Brothers Karamazov. Harmondsworth: Penguin.

Douglas, Mary (1966) Purity and Danger: An Analysis of the Concepts of Pollution and Taboo. London: Routledge and Kegan Paul.

Elias, Norbert (1978) The Civilising Process, the History of Manners. Oxford: Basil Blackwell.

Gellner, Ernest (1995) “The Price of Velvet: Thomas Masaryk and Václav Havel”. Czech Sociological Review 3 (1), 45-57.

Goffman, Erving (1961) Asylums, Essays on the Social Situation of Mental Patients and other Inmates. New York: Anchor.

Hašek, Jaroslav (1973[1923]) The Good Soldier Švejk and his Fortunes in the World War. Translated by Sir Cecil Parrott. Harmondsworth: Penguin.

Hašek, Jaroslav (1981) The Red Commissar. Translated by Sir Cecil Parrott. London: Abacus.

Hašek, Jaroslav (1991) The Bachura Scandal and Other Stories and Sketches. Translated by Alan Menhennet. London: Angel.

Havlíček, Tomáš (2005) "Secularisation of the Religious Landscape”. In Knippenberg, Hans (ed.) The Changing Religious Landscape of Europe, Amsterdam: het Spinhuis, 190-200.

Hermann, A. H. (1975) A History of the Czechs. London: Allen Lane.

Kaminsky, Howard (1967) The History of the Hussite Revolution. Berkeley: University of California Press.

Knippenberg, Hans (2005) The Changing Religious Landscape of Europe, Amsterdam: het Spinhuis.

Kovály, Heda Margolis (1997) Under a Cruel Star, A Life in Prague, 1941-1968. New York: Holmes and Meier.

Lewis, Sinclair (1955[1922]) Babbitt. New York: New American Library.

Martin, David (1978) A General Theory of Secularisation. Oxford: Basil Blackwell.

Menhennet, Alan (1991) Introduction to Hašek, Jaroslav (1991) The Bachura Scandal and Other Stories and Sketches. London: Angel, 7-12.

Okey, Robin (2001) The Habsburg Monarchy, 1765-1918. Basingstoke: Macmillan.

Parrott, Sir Cecil (1973) Introduction to Jaroslav Hašek, The Good Soldier Švejk and his Fortunes in the World War. Harmondsworth: Penguin, vii-xxii.

Parrott, Sir Cecil (1975) The Bad Bohemian, The Life of Jaroslav Hašek, Creator of the Good Soldier Švejk. London: Bodley Head.

Parrott, Cecil (1982) Jaroslav Hašek, A Study of Švejk and the Short Stories. Cambridge: Cambridge University Press.

Parrott, Sir Cecil (1985) Preface to Jaroslav Hašek, The Red Commissar. London: Abacus, xi-xiv. Pytlík, Radko (1999) Idiots Have Priority, The Good Soldier Švejk and the Author, Jaroslav Hašek. Prague: Emporious.

Rabelais, François (1955[1532]) Pantagruel roy des dipsodes (Pangagruel, Book 1). In: Rabelais, François. Oeuvres Complètes, Paris, Gallimard.

Sked, Alan (2001) The Decline and Fall of the Habsburg Empire, 1815-1918. London: Longman.

Steed, Henry Wickham (1914) The Habsburg Monarchy. London: Constable.

Taylor, A. J. P. (1948) The Habsburg Monarchy, 1809-1918. London: Hamish Hamilton.

Velinger, Jan (2003) "Fans of 'The Good Soldier Švejk' salute genius of author Jaroslav Hašek". Radio Praha. Available online at: http://www.radio.cz/en/section/curraffrs/fans-of-the-good-soldier-svejk-salute-genius-of-author-jaroslav-hasek. Accessed on $6^{\text {th }}$ January, 2013. 
Zamoyski, Adam (1987) The Polish Way, a Thousand Year History of the Poles and Their Culture. London: John Murray.

Zeman, Zbyněk (1961) The Break-up of the Habsburg Empire. London: Oxford University Press. Zeman, Zbyněk (1976) The Masaryks, the Making of Czechoslovakia. London: Weidenfeld and Nicolson.

Christie DAVIES is a graduate of Cambridge University (MA, $\mathrm{PhD}$ ) and has an honorary doctorate for his work on humour from the Dunerea de Jos University of Galaţi. He has written many scholarly books about humour, most recently Jokes and Targets (2011). He was President of the International Society of Humour Studies in 2008-9 and received their lifetime achievement award in 2012. He has given guest lectures at Charles University Prague and the Prague School of Economics and taught both economics and Hašek to Czech and Polish students at a Liberální Institute summer school. He has been an enthusiastic reader of the English translations of Hašek's work for forty years and in 1986 he was sponsored by the British Council to visit Czechoslovakia to study Hašek and Švejk. His articles on Hašek's literary style have been published in the Polish journal Stylistyka. He has also published extensively on the sociology and history of morality and religion, including his book The Strange Death of Moral Britain 2006, and he taught this subject for many years at British universities.

Address: Professor Christie Davies, University of Reading, Whiteknights, Reading, RG6 6AA, United Kingdom. [email: j.c.h.davies@reading.ac.uk] 